\title{
Pemanfaatan Aplikasi Quizizz Sebagai Media Pembelajaran Ditengah Pandemi Pada Siswa SMA
}

\author{
Unik Hanifah Salsabila, Iefone Shiflana Habiba, Isti Lailatul Amanah', Nur \\ Asih Istiqomah, Salsabila Difany \\ Universitas Ahmad Dahlan, Yogyakarta, Indonesia \\ Email : nur1800031201@webmail.uad.ac.id
}

\begin{abstract}
ABSTRAK
Keberadaan Pandemi Covid-19 mengharuskan pemerintah Indonesia mengambil kebijakan sistem belajar di rumah di berbagai tingkat pendidikan. Kebijakan ini disertai dengan intruksi penerapan pembelajaran jarak jauh atau pembelajaranonline (daring). Untuk mempermudah pembelajaran online (daring) diperlukan media yang relevan, dengan menggunakan media aplikasi Quizizz yang bernilai edukasi diharapkan peserta didik dapat belajar dengan inovatif sehingga akan lebih mempermudah dalam melaksanakan pembelajaran di kelas.Penelitian ini menggunakan metode studi kepustakaan atau library research, yaitu membaca, menelaah, dan mengkaji buku-buku maupun tulisan-tulisan yang berkaitan dengan pembahasan.Berdasarkan penelitian hasil yang dapat dicapai dalam aplikasi Quizizz sebagai media pembelajaran, yakni :(1)Perhatian siswa dalam menggunakan hand phone dalam proses pembelajaran, (2)Pemahaman siswa memahami soal secara mandiri(3) Keaktifan,baik bertanya mengenai materi maupun mengevaluasi dan mencatat materi. (4)Ketelitiansiswa terhadap soal dan manajemen waktu. (5) Ketenangan dalam mengerjakan soal atau kuis. Dengan demikian dapat disimpulkan bahwa media aplikasi Quizizz sangat efektif digunakan dalam proses pembelajaran.
\end{abstract}

Kata Kunci :Pembelajaranonline (daring),AplikasiQuizizz, Media Pembelajaran,

\section{PENDAHULUAN}

Pembelajaran merupakan kegiatan utama dari proses pendidikan di sekolah yang bertujuan untuk menghasilkan perubahan tingkah laku. Perubahan tersebut meliputi kognitif, afektif dan psikomotor. Kegiatan pembelajaran ini memerlukan keaktifan belajar, partisipasi dan komunikasi interaktif antara guru dan siswa. Aktivitas belajar harus dirancang sedemikian rupa sehingga dapat mencapai tujuan pembelajaran. Keberhasilan dalam proses pembelajaran dapat dilihat dari pemahaman konsep, penguasaan materi dan prestasi belajar peserta didik. Peserta didik dengan tingkat pemahaman konsep dan penguasaan materi yang tinggi, maka semakin tinggi pula prestasi yang diraih.Selain itu, faktor penentu 
keberhasilan pembelajaran lainnya adalah ketepatan penerapan model dan media pembelajaran.Seorang pendidik diharuskan memahami metode pembelajaran terutama yang berkaitan dengan model-model pembelajaran.Pengertian media pembelajaran adalah merancang pembelajaran dan merencanakan kegiatan belajar mengajar. Sedangkan manfaat media pembelajaran adalah memperjelas penyajian materi dan informasi sehingga dapatmemperjelas dan meningkatkan proses dan hasil belajar. Media pembelajaran juga dapat mengarahkan perhatian siswa sehingga dapat menimbulkan motivasi belajar yang berdampak pada keaktifan dan hasil belajar.

Untuk mengikuti tantangan pembelajaran berbasis digital,seiring dengan berkembangnya Teknologi dan Informasi, sehingga mendorong terciptanya pemanfaatan media pembelajaran yang inovatif, efektif, dan efisien. Untuk itu dibutuhkan sebuah media pembelajaran berbasis digital agar dapat dimanfaatkan dalam upaya meningkatkan hasil belajar siswa(Irwan dkk, 2019). Media pembelajaran diperlukan guru untuk menjadi alat bantumenyampaikan materi pelajaran.

Indonesia yang saat ini sedang menghadapi pandemi virus covid-19, mengharuskan siswa untuk belajar di rumah, guna menghindari dan memutus rantai penyebaran virus. Guru dan siswa harus melakukan pembelajaran secara online atautidak tatap muka di kelas seperti biasanya. Sehingga, hal ini menuntut siswa dan guru harus belajar dan melakukan pembelajaran secara online atau daring. Pembelajaran tetap harus berlangsung dengan maksimal, meskikeadaan sedang mengalami transisi besar-besaran di tengah pendemi covid-19 agar generasi emas tidak ketinggalan dalam proses usaha kemajuan belajar dan tetap melakukan pembelajaran.

Oleh karena itu guru harus membekali para siswa dengan pendidikan dan keterampilan yang tidak hanya meliputi keterampilan bertahan hidup tapi juga keterampilan berpikir kritis, konstruktif, inovatif dan berkarakter.Pada saat pembelajaran online (daring), optimalisasi dalam komunikasi jarak jauh tidak terlepas dengan penggunaan handphone, tablet, atau laptop serta koneksi internet yang dapat dimanfaatkan sebagai bagian dari kegiatan pembelajaran. Hal ini menjadi tantangan untuk guru agar tetap dapat menciptakan pembelajaran yangmenyenangkan, menarik dan aktif dan tetap dapat mencapai tujuan pembelajaran. Mengingat akan adaptasi baru, yang mau tidak mau harus bisa di terima dengan sedemikian rupa.

Salah satu media pembelajaran yang menarik, memiliki sifat interaktif yang mengutamakan kerjasama, komunikasi, dan bisa menimbulkan interaksi antar siswa adalah melalui permainan, yang mempunyai karakteristik untuk menciptakan motivasi dalam belajar, yaitu khayalan (fantasy), tantangan (challenges) dan keingintahuan (curiosity) (Irwan dkk, 2019).

Permainan (games)sendiri merupakan segala konteks yang menimbulkan interaksi satu dengan yang lain antara pemain dengan cara mengikuti atuan-aturan 
yang ada serta telah ditentukan dalam mencapai sebuah tujuan(Sadiman dkk, 2010). Banyak media pembelajaran yang telah disuguhkan, yang bisa diterapkan oleh guru, salah satunya yaitu media pembelajaran berbasis permainan,tentu juga bisa dimanfaatkan sebagai sarana menyampaikan materi dalam proses pembelajaran yaitu untuk mengukur pemahaman siswa selama mendapatkan materi yang telah diajarkan. Quizizz sendiri, merupakan aplikasi permainan pendidikan yangsifatnya naratif dan fleksibel, selainbisa dimanfaatkan sebagai sarana menyampaikan materi, Quizizz juga bisa digunakan, sebagai media evaluasi pembelajaran yang menarik dan menyenangkan. Kegiatan pembelajaran dirumah tentu dapat dengan mudah menjadi kegiatan yang membosankan bagi siswa. Sehingga, dengan adanya kemudahan akses media pembelajaran sekarang ini, Guru dapat menggunakan, kemudian mengembangkan media evaluasi melalui aplikasi Quizizz, sehingga dapat mencapai tujuan pendidikan.

Indonesia memiliki generasi emas yang tengah terombang-ambing akan kencangnya arus transisi pandemi. Generasi pemuda-pemudi yang kini duduk di bangku Sekolah Menengah Atas, sungguh-sungguh membutuhkan proses pembelajaran yang fleksibel dan tentu memberikan mereka pemahaman secara konkret dari materi yang disampaikan oleh Guru. Lahirnya teknologi yang menjadi salah satu bagian dari media pembelajaran, adalah untuk memberikan kemudahan, kemudian menghasilkan media pembelajaran berupa aplikasi permainan Quizizz yang eksistensinya kian ramai di gadang-gadangkan sebagai media pembelajaran tepat di tengah pandemi, terutama siswa SMA. Aspek Kognitif, Afektif, dan Psikomotorik, jelas bisa ditumbuhkan melalui suatu permainan dalam lingkup pembelajaran.

Berbagai macam kajian terkait dengan pemanfaatan aplikasi Quizizz, menunjukkan kemanfaatan yang didapat, menggambarkan bahwa Quizizz bisa meningkatkan kompetensi setiap siswa dan keahlian siswa. Pemanfaatan media pembelajaran Quizizz, adalah salah satu upaya mengakomodir permasalahan media pembelajaran di Indonesia yang tidak bisa diterapkan secara konvensional dengan pembelajaran lain yang berbasis Teknologi Informatika dan Komputer. Padahal, model pembelajaran pendidikan berbasis teknologi bisa di strategikan secara naratif yang bersifat prespektif. Sehingga, menghasilkan rumusan upaya pemecahan masalah melalui pemanfaatan aplikasi Quizizz, terutama pada siswa SMA. Siswa SMA yang sedang tumbuh-tumbuhnya olah emosi, terkadang bisa memperlambat proses kinerja otak, ketika sedang kegiatan proses belajar mengajar berlangsung. Untuk menciptakan atmosfer pembelajaran yang lebih hidup, pemanfaatan aplikasi Quizizz bisa menjadi upaya tersebut, tanpa menghilangkan esensi dari materi yang telah disampaikan oleh guru. Permainan Quizizz dapat membantu mendorong motivasi belajar siswa dan meningkatkan hasil belajar. Hal tersebut sejalan dengan pendapat Dewi, C. K. (2018: 43), yang menyatakan, bahwa pembelajaran berbasis permainan mempunyai potensi yang baik untuk dijadikan 
sebagai media pembelajaran yang efektif karena dapat merangsang komponen visual dan verbal.

Inilah yang akan menjadi pokok kajian dalam penelitian ini, mengusung topik hangat yang kian ramai dibincangkan, dengan tema teknologi pendidikan sebagai media pembelajaran,dengan judul "Pemanfataan Permainan Quizizz Sebagai Media Pembelajaran Pada Siswa SMA Di Tengah Pandemi". Sehingga, pendidikan Indonesia tidak tertinggal akan perubahan zaman serta kemajuan yang menyertainya.

\section{METODE PENELITIAN}

Artikel ini menggunakan penelitian metode deskriptif (mendeskribsikan) bagaimana integrasi Keislaman pada Pembelajaran daring yang dianalisismelalui literature kepustakaan yang mendukung.Pendekatan ini menggunakan pendekatan kualitatif dengan data deskriptif yaitu data yangdikumpulkan dengan menggunakan kata-kata. Pembahasan masalah di artikel ini penulismenggunakan jenis penelitian kepustakaan Penelitian kepustakaan dilakukandengan mengumpulkan data dan informasi dari sumber pustaka, seperti artikel, buku, jurnal,dokumen dan sumber pustaka lainnya.

\section{PEMBAHASAN}

\section{Aplikasi Quizizz sebagai media pembelajaran}

Salah satu kebijakan yang tertuang dalam propenas tahun 1999-2004adalah peningkatan mutu pendidikan nasional. Berbagai upaya dalam rangka meningkatkan mutu 2010 pendidikan akan dan telah dilaksanakan, yang diantaranya melengkapi sekolah-sekolah dengan berbagai sarana dan sumber belajar. Hal ini sejalan dengan UU No.2 Tahun 1989 tentang SISDIKNAS, yang memberikan syarat agar setiap satuan pendidikan jalur sekolah, dapat menyediakan sarana belajar yang memadai sebagai upaya mendukung akan pelaksanaan pendidikan.Menyadari akan keterbatasan kemampuan untuk mewujudkan pemerataan sarana pembelajaran di Indonesia, menjadikan Guru harus memiliki berbagai macamupaya kreatif dan inovatif dalam mewujudkan prose pembelajaran yang menyenangkan juga mudah di fahami, seperti memperbanyak lagi varisi strategi pembelajaran, baik dari penunjang materi, sarana, dan yang terpenting adalah media pembelajaran.

Mengingat transisi pandemi, yang mengharuskan kegiatan belajar mengajar dilakukan secara online. Sehingga, teknologi memiliki peran yang teramat terhadap keberlangsungan proses belajar mengajar selama pandemi.Media pembelajaran yang tepat menjadi satu hal penting demi menunjang keberhasilan pendidikan. Berperannya media pembelajaran sebagai wadah penyampaian pesan 
pembelajaran kepada sasaran pembelajaran. Hal ini di atur penuh oleh guru, guna menilai dan menimbang perkembangan pembelajaran.

Pada siswa SMA, strategi pembelajaran ceramah dengan media penyampaian materi secara langsung seolah-olah guru memberikan ceramah, tidak bisa dikatakan sebagai strategi yang efektif. Siswa SMA yang tengah tumbuhtumbuhnya akan upaya pencarian jati diri, tidak terlepas begitu saja dengan olah emosi. Kondisi ditengah pandemi, tak ayal menjadikan siswa SMA justru cenderung cepat stress bahkan depresi. Sehingga tidak bisa dipungkiri bila akhirnya materi yang disampaikan oleh guru tidak bisa diterima dengan mudah oleh siswa-siswa nya.

Semakin cepatnya arus globalisasi, memunculkan pula arus lain dalam perkembangan teknologi, yang akhirnya lahir aplikasi Quizizz sebagai media pembelajaran, penunjang keberlangsungan kegiatan belajar mengajar ditengah pandemi.Aplikasi Quizizz bersifat online, yang artinya dapat digunakan dengan mudah jika didukung dengan akses internet yang memadai.

Pengembangan dari media pembelajaran Quizizz, perlu dilakukan secara berkesinambungan, agar Quizizz bisa menjadi satu aplikasi kompetitif sebagai media pembelajaran, di tengah adaptasi pandemi covid-19. Pemanfaatan media pembelajaran sendiri, tidak dapat dilepaskan begitu saja dengan pola-pola pembelajaran. Pola -pola pembelajaran yang diorganisasikan, kemudian di terapkan berdasarkan batasan teknologi pendidikan. Pada dasarnya, terdapat 4 pola pembelajaran yang diterapkan di Indonesia, 1) Pola Tradisional, yakni hubungan Guru kepada siswa secara langsung, 2) Pola Guru dengan media, 3) Pola pembelajaran bermedia, 4) Pola pembelajaran dengan media saja.

Pemanfaatan aplikasi Quizizz sebagai media pembelajaran masuk dalam kategori pola pembelajarana nomor 3, dimana menempatkan media sebagai komponen sistem pembelajaran menjadi setara dengan komponen lainnya. Pola pembelajaran yang dibuat dan diberdayakan melalui aplikasi Quizizz adalah pola multimedia intaraktif. Aplikasi Quizizz memiliki kelebihan-kelebihan yang dapat dengan mudah di manfaatkan selain media pembelajaran, juga bahan evaluasi pembelajaran, sebagai contoh, terdapat data dan perhitungan statistik kinerja peserta didik, yang hasilnya bisa menggambarkan sejauh mana pemahaman siswa terhadap materi, nantinya menjadi bahan ukur evaluasi pembelajaran secara keseluruhan.Sehingga, memberikan warna baru terhadap olah evaluasi guru dan pola pembelajaran yang menyenangkan bagi siswa-siswi.

Terdapat berbagai macam fitur lain yang tersediadalam aplikasi Quizizz, yang bisa dimanfaatkan menjadi salah satu sarana Guru dalam memberikan tugas atau pekerjaan rumah. Disamping mengerjakan tugas, siswa bisa merasakan pembelajaran yang tidak terlalu berat dalam memikirkan jawaban, karena dalam aplikasi Quizizz memiliki tampilan segar dan kaya akan hal-hal yang menyenangkan. Sebuah permainan memang tidak akan lepas denga unsur kreatif, inovatif, petualangan, dan menyenangkan, yang kemudian bisa menumbuhkan 
motivasi positif keinginan belajar dari setiap siswa.Sehingga, dapat mewujudkan cita-cita dan tujuan pendidikan secara konkret dan rata.

Penggunaan Quizizz sangat mudah. Kuis interaktif ini memiliki hingga 45 pilihan jawaban termasuk jawaban yang benar. Bisa juga ditambahkan gambar ke latar belakang pertanyaan dan menyesuaikan pengaturan pertanyaan sesuai keinginan anda. Bila kuis sudah jadi, dapat dibagikan kepada siswa dengan menggunakan kode 6 digit yang dihasilkan. Quizizz dapat digunakan sebagai strategi pembelajaran yang baik dan menyenangkan tanpa kehilangan esensi belajar yang sedang barlangsung. Bahkan strategi ini dapat melibatkan partisipasi siswa secara aktif sejak awal (Noor, 2020)

\section{Cara Membuat Akun dan Pengoperasian Aplikasi Quizizz}

Media pembelajaran aplikasi Quizizz sangat mudah pembuatannya, yakni dengan menyiapkan terlebih dahulu materi, dalam bentuk pertanyaan-pertanyaan dan jawaban alternatif dalam aplikasi Quizizz. Setelah selesai menyusun materi kedalam pertanyaan dengan seluruh konten lainnya yang hendak di sisipkan, kemudian membuka dan masuk pada aplikasi Quizizz, melalui webnya, yaitu www.Quizizz.com. Sebagaima tersedia di playstore atau laman internet lainnya.

Bagi pendatang baru, atau yang belum memiliki akun untuk dapat mengoperasikan aplikasi Quizizz, diharuskan untuk mendaftar terlebih dahulu, dan akan mendapatkan akun, guna mempermudah akses terhadap aplikasi Quizizz. Tata caranya yaitu, dengan klik tulisan sign up yang tertera, kemudian melengkapi keperluan biodata secara singkat dalam pendaftaran, agar menandakan bahwa itu adalah Anda. Jika sudah terdaftar sebagai akun, maka akun tersebut bisa digunakan secara bijak dalam mengakses aplikasi Quizizz, yakni dengan cara, klik tulisan log indidalam aplikasi Quizizz, dengan mengisikan ketentuan akun, yaitu email dan password yang digunakan ketika melakukan pendaftaran sebelumnya.

Ketika sudah masuk kedalam web dan tentu sudah terdaftar sebagai akum dari aplikasi Quizizz, kita akan dihadapkan dengan pemandangan pada library, yang mana terdapat koleksi media kuis, yang telah di suguhkan oleh Sang Pembuat kuis sebelum-sebelumnya. Selain itu, kita bisa dengan leluasa memilih kuis-kuis yang tersedia di aplikasi Quizizz, sesuai dengan kebutuhan guru dalam mengoperasikan aplikasi Quizizz. Dari namanya yang di awali dengan kata Quiz, tentu terdapat berbagai macam variasi kuis yang disuguhkan. Akan tetapi, untuk meningkatkan kreativitas dari setiap pemiliki akun, Quizizz memberikan kemudahan untuk bisa membuat kuis sendiri, yang dikuiskan melalui kreasi diri sendiri, dengan klik tulisan create my quiz. Berikut secara ringkas tata cara dan pengoperasian aplikasi Quizizz :

1. Buka web, ketik Quizizz

2. Bila belum memiliki akun, klik sign up

3. Isi segala ketentuan pendaftaran akun 
4. Masuk ke aplikasi Quizizz, klik $\log$ in

5. Isi dengan email dan password yang digunakan ketika mendaftar akun

6. Tentukan model kuis, bisa membuat sendiri dengan klik create my quiz

Demikian variasi media pembelajaran melalui aplikasi Quizizz bisa dimanfaatkan dan di operasikan sebagaimana mestinya, dengan memanfaatkan kemudahan teknologi pendidikan di tengah pandemi.Adapun pengoperasian dari aplikasi Quizizz, yaitu sebagai berikut :

1. Masuk ke www.quizizz.com

2. Klik tulisan $\log$ in

3. Kemudian, klik tulisan teacher, sebagai pengajar

4. Masukkan identitas diri, berupa username email, dan password

5. Jika sudah dinyatakan masuk, kemudian buat kuis, pada tulisan create a quiz

6. Muncul tampilan Lets Create a Quiz

7. Masukkan nama kuis, contoh : Pelajaran Agama Islam

8. Kemudian klik save

9. Muncul tampilan Selanjutnya, klik create new question

10. Tuliskan pertanyaan pada kolom yang tersedia, "Write Question Here", lalu masukkan opsi jawaban (apabila menggunakan multiple choice/pilihan ganda) pada kolom "Answer option 1, answer option 2, dan seterusnya"

11. Beri tanda centang, kolom jawaban yang benar

12. Kemudian atur durasi mengerjakan dalam setiap soal

13. Klik save

14. Apabila telah menyelesaikan pengisian kuis, klik "Finish Quiz"

15. Kemudian, akan muncul tampilan quiz detail (aturlah kelas berapa kuis itu akan di tujukan), lalu klik save details

16. Kemudian, muncul tampilan berikutnya, pilihlah "Homework", apabila hendak digunakan sebagai PR, serta pilih "Play Live", apabila hendak digunakan sekarang.

17. Masukkan deadline atau batas waktu mengerjakan (atur tanggal serta jam) lalu klik "Procced"

18. Kemudian, muncul tampilan berikutnya, yaitu kode yang digunakan untuk masuk dalam pengerjaan kuis.

19. Kemudian membuka Link "http://quizizz.com/admin/"

Demikian cara dalam pengoperasian aplikasi Quizizz sebagai media pembelajaran.

Pemanfaatan Aplikasi Quizizz Sebagai Media Pembelajaran Ditengah Pandemi Pada Siswa SMA 
Sebelum memahami secara mendalam mengenai pemanfaatan aplikasi Quizizz sebagai media pembelajaran, aplikasi ini tentu memiliki beberapa kelebihan yang tentu dapat menunjang keberhasilan proses pembelajaranpada siswa SMA :

- Bagi Guru/Pendidik, memudahkan dalam membuat soal.

- Ketika siswa menjawab soal atau kuis dengan benar, setelah itu akan muncul berapa poin yang didapatkan dalam satu soal, juga mendapatkan ranking atau peringkat berapa dalam menjawab kuis tersebut.

- Bilamana siswa menjawab kuis tersebut salah, maka akan muncul jawaban yang benar, guna koreksi mandiri bagi siswa.

- Ketika telah dinyatakan selesai mengerjakan kuis, pada sesi akhir atau penutup, sebelumnya akan di tampilkan review questionguna mencermati kembali jawaban yang telah dipilih.

- Dalam mengerjakan kuis, setiap siswa mendapatkan soal kuis yang berbedabeda, karena telah di acak secara otomatis, sehingga meminimalisir kecurangan.

Disamping dengan adanya kelebihan, tentu tidak bisa dipungkiri dengan adanya kekurangan atau kelemahan dari aplikasi Quizizz sebagai media pembelajaran, yakni sebagai berikut :

- Jaringan atau internet, yang sewaktu-waktu bermasalah

- Ketika mengerjakan, siswa dapat membuka tab baru, itu artinya siswa bisa masuk dengan mudah menggunakan lain untuk mencari jawaban.

- Dalam permasalahan waktu, siswa yang mulanya bisa mendapatkan peringkat atas, memiliki kemungkinan penurunan peringkat, dikarenakan manajemen waktu yang kurang tepat.

- Akan menjadi kendala atau permasalahan tambahan, bila siswa terlambat bergabung.

Demikian uraian mengenai kelebihan dan kelemahan dari aplikasi Quizizz yang di gunakan sebagai media pembelajaran, sehingga memudahkan pembaca dalam memahami pemanfaatan aplikasi Quizizz.

Karya-karya yang ada dalam aplikasi Quizizz, dapat dengan mudah diperoleh, karena sudah banyak diposting dalam situsnya. Namun, akan menjadi lebih baik apabila pendidik atau guru berkreasi sendiri dalam membuat soal, karena dapat menyesuaikan dengan kebutuhan belajar siswa, sesuai dengan tujuan dan pembelajaran yang telah dirancang. Bila sudah menemukan set kuis yang telah ditentukan atau dibutuhkan, kita dapat memanfaatkannya dengan menjadikannya bersifat live, solo atau PR di kelas daring selama pandemi.

Selain itu, kelengkapan dari aplikasi Quizizz, sangat mendukung dalam mensukseskan proses pembelajaran di berbagai jenjang dan mata pelajaran, termasuk siswa SMA. Pengembangan dan pemanfaatan suatu media pembelajaran, sangat diperlukan guna melengkapi hal-hal yang masih belum lengkap ketika membuat dan memanfaatkan aplikasi, karena terkait kebutuhan siswa atau peserta didik. Pengembangan dan inovasi dari media pembelajaran membantu mengakomodir pembelajaran, hingga kemudian mampu membentuk karakteristik 
dan meningkatkan kompetensi serta motivasi dalam belajar. Secara garis besar, pengembangan terhadap media pembelajaran itu perlu dilakukan, agar dapat segera mewujudkan pendidikan yang kaya akan progres serta kemajuan.

\section{Hasil Belajaryang dapat dicapai}

Menurut Dimyati dan Mudjiono (2015: 4), hasil belajar adalah hasil yang dicapai dalam bentuk angka - angka atau skor setelah diberikan tes hasil belajar pada setiap akhir pembelajaran. Nilai yang telah didapatkan oleh siswa, bisa menjadi acuan dalam melihat penguasaan siswa atau peserta didik dalam menerima materi pembelajaran. Sedangkan hasil belajar adalah sejumlah pengalaman yang diperoleh siswa atau peserta didik yang mencakup ranah kognitif, afektif, psikomotorik.

Bahkan, belajar tidak hanya penguasaan terhadap konsep teori mata pelajaran saja, akan tetapi juga penguasaan, kebiasaan, dan persepsi, kesenangan dan minat bakat, kesesuaian sosial, macam-macam keterampilan, cita-cita, suatu keinginan, serta harapan. Hal tersebut didukung dengan pendapat Rusman (2017: 130), dimana menyatakan bahwa hasil belajar itu dapat terlihat dari terjadinya perubahan dari persepsi serta perilaku, termasuk juga perbaikan sikap atau akhlak.

\section{KESIMPULAN}

Dalam mewujudkan tujuan serta cita-cita pendidikan di Indonesia, membutuhkan berkali-kali lipat usaha, mengingat segala kekurangan yang dimiliki. Teknologi hadir sebagai sarana kemudahan dalam menjalankan kehidupan, termasuk pendidikan. Disamping adanya transisi pandemi, pendidikan memiliki tantangan untuk bisa mengoptimalkan peran teknologi dalam ikut andil mensukseskan pendidikan, baik dari aspek proses pembelajaran, media pembelajaran, strategi pembelajaran, hingga evaluasi pembelajaran. Seluruh peserta didik, selalu membutuhkan model atau strategi pembelajaran yang menyenangkan, begitu juga dengan siswa SMA, terlepas dari usia berapa masing-masing mereka.

Salah satu media untuk menciptakan suasana pembelajaran yang menyenangkan tapi tidak menghilangkan atau menurunkan pemahaman peserta didik mengenai materi serta memanfaatkan perkembangan teknologi, adalah dengan aplikasi game atau permainan. Permainan atau game online yang bisa dijadikan alternatif dalam menyampaikan materi pembelajaran terhadap siswa SMA, yakni aplikasi Quizizz. Permainan edukatif satu ini, memberikan begitu banyak manfaat yang tentu dapat dirasakan dalam media pembelajaran, karena media ini menarik dan dapat memotivasi secara kerja otak dan olah manajemen waktu.

Upaya pemanfaatan aplikasi Quizizz digadang-gadang bisa menjadi alternatif media pembelajaran, dimana mengutamakan kreatifitas, manajemen waktu, hingga evaluasi mandiri dari siswa. Dengan memberdayakan aplikasi Quizizz sebagai media pembelajaran, pendidikan di Indonesia agaknya bisa cukup 
tenang dalam melakukan evalusi, sebagai mana yang telah dijelaskan. Dimana dalam aplikasi Quizizz, guru bisa melakukan penilaian atau evaluasi lebih tepat.

Akan tetapi, terlepas dari itu semua, pemanfaatan aplikasi Quizizz sebagai media pembelajaran yang efektif, bisa tercapai bilamana, guru memperhatikan akan kebutuhan, kekurangan dan perbedaan siswa atau peserta didik. Selain itu, juga tidak hanya terpaku pada aplikasi Quizizz saja, tapi juga memberdayakan aplikasi lain penunjang keberlangsungan dari proses pembelajaran. Sehingga, meski dalam kondisi apapun, pemerataan pendidikan tetap bisa dirasakan oleh siapa saja, termasuk siswa-siswa SMA, yang mengemban sebagai pemuda-pemudi berbakat penerus generasi emas bangsa, baik dalam aspek pendidikan, ekonomi, sosial, hingga politik. Maka, tujuan dan cita-cita pendidikan yang telah ditetapkan dapat terwujud sebagaimana mestinya perlu di wujudkan.

\section{DAFTAR PUSTAKA}

Agung setiawan dkk. “Implementasi Media Game Edukasi Quizizz Untuk Meningkatkan Hasil Belajar Matematika Materi Sistem Persamaan Linear Tiga Variabel kelas X Ipa 7 SMA Negri 15 semarang Tahun Pelajaran 2019/2020". Seminar Nasional Edusaintek FMIPA UNIMUS,2019.

Bahar, Ayunara. Membuat Kuis Interaktif Kelas dengan Quizizz. Tersedia pada https://www.ahzaa.net/2017/08/membuat-kuis-interaktif-kelasdengan.html(diaksestanggal 19 Oktober 2020). 2017

Dewi, C. K. (2018). Pengembangan Alat Evaluasi Menggunakan Aplikasi Kahoot pada Pembelajaran Matematika Kelas X. Skripsi S1. Fakultas Tarbiyah dan Keguruan Universitas Islam Negeri Raden Intan Lampung (2020) dari: http://repository.radenintan.ac.id/4286/1/SKRIPSICAHYAKURNIA.pdf

Dimyati, dan Mudjiono. Belajar dan Pembelajaran,Jakarta : Rineka Cipta, 2015.

Irwan, I., Luthfi, Z. F., \& Waldi, A.Efektifitas Penggunaan Kahoot! untuk Meningkatkan Hasil Belajar Siswa [Effectiveness of Using Kahoot! to Improve Student Learning Outcomes]. Pedagogia : Jurnal Pendidikan 1.8 (2019).

Isratul Aini, Yulia. Pemanfaatan Media Pembelajaran Quizizz untuk Pembelajaran Jenjang Pendidikan Dasar dan Menengah di Bengkul. Jurnal Kependidikan 2.25 (2019).

Noor, S. Penggunaan Quizizz dalam Penilaian Pembelajaran pada Materi Ruang Lingkup Biologi untuk Meningkatkan Hasil Belajar Siswa Kelas X. 6 SMAN 7 Banjarmasin. Jurnal Pendidikan Hayati 6.1 (2020): 1-7.

Rusman. Belajar dan Pembelajaran: Berorientasi Standar Proses Pendidikan, Jakarta : Kencana, 2017.

Sadiman, A. S., Rahardjo, R., Haryono, A., dan Rahardjito. Media Pendidikan, Jakarta: Pustekkom Dikbud dan PT RajaGrafindo Persada, 2010. 